\title{
Pengaruh Kualitas Produk Dan Harga Terhadap Keputusan Pembelian Produk Kosmetik Wardah Pada Counter Wardah Di Borobudur Kediri
}

\author{
Jasinta Pangastuti; Sudjiono; Eni Prastiti \\ Fakultas Ekonomi - Universitas Kadiri \\ E-mail : sudjiono@unik-kediri.ac.id
}

\begin{abstract}
The sample in this study were some of the consumers who had purchased Wardah cosmetic products at the Wardah counter in Borobudur Kediri. The sampling technique uses non-probability sampling using purposive sampling sampling technique. This study researchers determined the number of samples as many as 30 respondents. This study uses two variables as the object of research, namely the independent variable of product quality (X1) and price (X2) and the dependent variable is the purchasing decision $(Y)$. In this study the researcher used a questionnaire that was filled out by the respondent, it was necessary to do the calculation using a Likert scale. The type of research used in this study is associative research, this research is included in the type of quantitative research. The Research Instrument Test uses Test Validity and Reliability. using data analysis in the form of (descriptive analysis, and multiple linear regression analysis and also using normality tests), hypothesis testing (partial significant testing ( $t$-test), test variables together ( $F$-test), coefficient of determination $(R \wedge 2)$ The test results partially show that product quality and price variables give a positive and significant influence on purchasing decisions.The results of the tests simultaneously show all the influential variables on purchasing decisions.The results of multiple linear regression analysis The regression coefficients of all independent variables show positive numbers. the most dominant independent variable is product quality $(X 1)$ with a regression coefficient of 0.551 while for the price variable $(X 2)$ is 0.385
\end{abstract}

Keywords: Product Quality, Price, Purchasing Decision

\begin{abstract}
ABSTRAK
Sampel dalam penelitian ini adalah sebagian dari konsumen yang telah membeli produk kosmetik Wardah di counter Wardah di Borobudur Kediri. Teknik pengambilan sampel menggunakan non-probability sampling dengan menggunakan teknik pengambilan sampel purposive sampling. Penelitian ini peneliti menentukan jumlah sampel sebanyak 30 responden. Penelitian ini menggunakan dua variabel sebagai objek penelitian yaitu variabel bebas kualitas produk (X1) dan harga (X2) dan variabel terikatnya keputusan pembelian (Y). Dalam penelitian ini peneliti menggunakan kuesioner yang telah diisi responden perlu dilakukan penghitungan dengan menggunakan skala Likert. Jenis penelitian yang digunakan dalam penelitian ini adalah penelitian asosiatif, penelitian ini termasuk dalam jenis penelitian kuantitatif. Uji Instrumen Penelitian menggunakan Uji Validitas dan reliabilitas. menggunakan analisis data berupa (analisis deskriptif, dan analisis Regresi Linear Berganda dan juga menggunakan uji normalitas), pengujian hipotesis (pengujian signifikan
\end{abstract}


parsial(uji-t), uji variabel secara bersama-sama(uji-F), koefisien determinasi $\left(K^{2}\right)$. Hasil pengujian secara parsial menunjukkan variabel kualitas produk dan harga memberikn pengaruh positif dan signifikan terhadap keputusan pembelian. Hasil pengujian secara simultan menunjukkan seтиa variabel berpengaruh terhadap keputusan pembelian. Hasil analisis regresi linear berganda Koefisien regresi dari semua variabel bebas menunjukkan angka positif. Dari kedua variabel bebas yang paling dominan berpengaruh adalah Kualitas produk (X1) dengan koefisien regresi sebesar 0,551 sedangkan untuk variabel harga(X2) sebesar 0,385.

Kata Kunci : Kualitas Produk, Harga, Keputusan Pembelian

\section{PENDAHULUAN}

Perkembangan dunia usaha yang sekarang ini semakin berkembang ini terbukti dengan semakin banyaknya penawaran produk, dengan begitu dunia usaha diharuskan membuat produk yang benar-benar memiliki nilai dan mutu yang baik sehingga dengan begitu akan terjadinya minat konsumen baru. Pastinya semua perusahaan menginginkan mendapat laba, karena dengan adanya laba yang didapat akan menjadikan kelangsungan hidup perusahaan dapat tercapai. Agar tujuan tersebut bisa diraih perlu seorang manager perusahaan untuk dapat mengelola seperti bahan baku, modal,tenaga kerja dan lainnya, agar biaya produksi yang dikeluarkan dapat seminimal mungkin karena dengan biaya tersebut akan mempengaruhi harga jual suatu produk. Dengan adanya persaingan yang semakin ketat ini yang menjadi sebuah tantangan untuk pemasar untuk mengusahakan produknya untuk bisa bersaing dengan produk lainnya. Maraknya persaingan usaha juga terjadi juga banyak diperusahaan yang bernaung di bidang kecantikan, bisa dilihat sekarang ini banyak produk-produk yang muncul dipasaran seperti misalnya produk kosmetik La tulipe, Make over, Wardah dan lainnya yang masih banyak dengan merek baru, Dengan kata lain dunia kecantikan sekarang ini berekembang dengan pesat apalagi didukung dengan produk-produk baru yang bermunculan. Sehingga dengan pesatnya industri atau dunia usaha kecantika sekarang ini para konsumen haruslah selektif untuk membeli barang yang pastinya harus memiliki nilai dan manfaat.

Salah satu perusahaan dibidang kecantikan yang berkembang pesat saat ini adalah kosmetik Wardah, Wardah merupakan produk yang dikeluarkan oleh PT Paragon Tecknologi and Innovation(PTI) yang berdiri pada tahun 1985 dengan nama awal PT Pusaka Tradisi Ibu dan akhirnya berganti nama menjadi PT Paragon Tecknologi and Innovation pada tahun 2011. Perusahaan ini didirikan oleh pasanagn suami istri Drs. H. Subakat, M.sc dan Dra. HJ. Nurhayati Subakat, Apt. Awal berdirinya 
hanya memproduksi perawatan rambut dan setelah itu merambah di dan mengembangkan merek Wardah dan memasuki pasar tata rias, dan sekarang ini berkembang pesat terbukti tahun 2018 Wardah banyak produknya yang mendapat peringkat top dari Top Brand Award, memang luar biasa bagi Wardah karena pencapainnyaini karena dapat bersaing dengan produk-produk kosmetik lainnya padahal wardah termasuk perusahaan tergolong baru dalam memasuki pasar kosmetik tetapi sekarang ini produknya sangat berkembang pesat

Kualitas produk sangat penting untuk dapat menarik minat konsumen terhadap produk yang ditawarkan, karena pada dasarnya setiap orang yang akan membeli suatu produk ataupun menggunakan produk jasa ingin memperoleh kualitas yang baik yang telah ia beli. Kualitas produk sendiri sangat penting untuk dipertimbangkan perusahaan dalam artian selalu mementingkan atau menigkatkan kualitas supaya konsumen tidak merasa rugi atau menyesal telah membeli produk yang telah perusahaan buat. Karena dengan adanya kualitas yang baik akan menarik minat konsumen baru ataupun konsumen yang pernah membeli akan melakukan pembelian ulang sehingga dengan semakin banyaknya pelanggan akan semakin perkembangannya perusahaan karena tujuan mereka untuk mendapat laba kemungkinan besar akan berlangsung.

Menurut (Lupiyoadi \& Hamdani 2006:131) yang menyatakan konsumen akan menyukai produk yang menawarkan kualitas, kinerja, dan pelengkap inovatif yang terbaik. Pada dasarnya produk yang berkualitas adalah produk yang memiliki nilai dan manfaat untuk konsumen. Hal tersebut sesuai dengan penelitian (Akbar: 2012) yang menyatakan bahwa kualitas produk paling berpengaruh terhadap keputusan pembelian.

Hirschman dan Stern dalam Sumarwan (2011:163) dalam (Lestari, 2016) mendefinisikan impulsive buying yaitu kecenderungan konsumen untuk melakukan pembelian secara spontan, tidak terefleksi, terburu-buru, dan didorong oleh aspek psikologis emosional terhadap suatu produk serta tergoda oleh persuasi dari pemasar.

Harga sendiri menimbulkan banyak presepsi dimata konsumen. Umumnya penilaiannya mereka beranggapan bahwa jika suatu produk yang mahal akan memiliki kualitas yang baik begitu sebaliknya jika harga tergolong murah dari pada produk sejenis tetapi dengan harga murah akan menimbulkan presepsi bahwa kualitas tersebut rendah atau adanya presepsi juga jika harga yang ditetapkan terlalu tinggi akan juga menimbukan presepsi bahwa harga yang ditetapkan terlalu tinggi padahal yang perlu diketahui juga terkadang memang jika ingin memiliki barang bagus dibutuhkan biaya 
yang tinngi tetapi itu juga bukan sebuah patokan atau tolak ukur jika harga mahal itu bagus memiliki mutu yang baik terkadang adanya pengambilan keuntungan yang besar yang hanya mengutamakan laba dari pada nilai dari barang itu sendiri. Jadi memang yang paling penting konsumen harus sangat selektif dalam membeli produk agar uang yang ditukarkan dengan produk ataupun produk jasa yang dibeli tidak sia-sia dan mendapat nilai dan manfaat dari produk itu sendiri.

Hal yang paling berperan dalam menetapkan harga disini adalah manager produksi perusahaan jadi manager produksi perusahaan mempunyai peran sangat penting dalam menetapkan harga sehingga penetapan harga yang di tetapkan dapat bersaing dengan saingan dipasar untuk merebut pangsa pasar sehingga tujuan kelangsungan perusahaan dapat tercapai, karena saat ini perkembangan dunia usaha yang berkembang dengan pesat pastinya akan banyak saingan dalam dunia usaha jadi dalam sebagian kasus biasanya akan terjadi permintaan harga berbanding terbalik yakni jika harga tinggi, maka permintaan suatu produk rendah begitu sebaliknya jika harga yang ditetapkan rendah maka permintaan suatu barang akan mengalami kenaikan dengan begitu perlu adanya kebijakan dalam perusahaan terutama pada manager produksi agar dalam menetapkan harga sesuai dengan pangsa pasar dan sesuai dengan nilai, manfaatnya dan kualitas produk. Dengan demikian harga disini akan mempengaruhi keputusan pembelian hal tersebut sesuai dengan penelitian sebelumnya yang dilakukan (Habibah \& Sumiati:2016) yang menyatakan harga dapat mempengaruhi keputusan pembelian, hal yang serupa juga dikemukakan oleh (Tjiptono, 2008) bahwa harga merupakan variabel paling penting dalam pemasaran dimana, harga dapat mempengaruhi konsumen dalam mengambil keputusan untuk membeli suatu produk, karena berbagai alasan.

Tempat dalam penelitian ini adalah di Counter borobudur, borobudur adalah toko swalayan dan toko toserba yang didalamnya ada beberapa counter selain Wardah dengan begitu rasanya perlu adanya penelitian sehingga peneliti disini akan menganalisis faktor yang mempengaruhi keputusan produk kosmetik wardah dicounter borobudur kediri yang meliputi: Kualitas produk dan Harga. Sehingga dengan demikian peneliti mengambil judul yaitu:

Pengaruh Kualitas Produk Dan Harga Terhadap Keputusan Pembelian Produk Kosmetik Wardah Pada Counter Wardah Di Borobudur Kediri. 


\section{Rumusan Masalah}

Adapun rumusan masalah penelitian ini adalah:

1. Apakah kualitas produk berpengaruh terhadap keputusan pembelian kosmetik wardah?

2. Apakah Harga berpengaruh terhadap keputusan pembelian kosmetik wardah?

3. Apakah kualitas produk dan harga berpengaruh terhadap keputusan pembelian kosmetik wardah?

\section{Manfaat Penelitian}

1. Bagi akademisi

Penelitian ini berguna untuk menambah pengetahuan sekaligus dapat menerapkan teori-teori dan konsep yang berkaitan dengan strategi pemasaran yang diperoleh dari perkuliahan,khususnya mengenai kualitas produk, harga, keputusan pembelian.

2. Bagi peneliti

Penelitian ini sebagai sarana aktualisasi diri, menambah pengetahuan serta dapat mengaplikasikan teori yang didapatkan selama bangku kuliah terutama dalam bidang pemasaran.

3. Bagi masyarakat umum

Penelitian ini diharapkan dapat memberikan wawasan atau pengetahuan bagi masyarakat umum jika ingin membeli suatu produk harus membertimbangkan kualitas produk dan harga sebelim melakukan keputusan pembelian.

\section{TINJAUAN PUSTAKA}

Tabel 1. Penelitian Terdahulu

\begin{tabular}{|c|c|c|c|c|}
\hline No & $\begin{array}{c}\text { NAMA } \\
\text { PENELITI }\end{array}$ & JUDUL & $\begin{array}{l}\text { VARIABEL } \\
\text { DAN ALAT } \\
\text { ANALISIS }\end{array}$ & HASIL PENELITIAN \\
\hline 1. & $\begin{array}{l}\text { Eva cahya, Harti } \\
\text { (2015) }\end{array}$ & $\begin{array}{l}\text { Pengaruh } \\
\text { kualitas } \\
\text { produk dan } \\
\text { harga } \\
\text { terhadap } \\
\text { keputusan } \\
\text { pembelian } \\
\text { Smartphone }\end{array}$ & $\begin{array}{l}\text { Jenis penelitian: } \\
\text { Deskriptif } \\
\text { Variabel } \\
\text { 1.kualitas produk } \\
\text { 2.harga } \\
\text { 3. keputusan } \\
\text { pembelian } \\
\text { Analisis data: }\end{array}$ & $\begin{array}{l}\text { Berdasarkan hasil uji t } \\
\text { variabel kualitas produk } \\
\text { memiliki pengaruh lebih } \\
\text { dominan dari pada variabel } \\
\text { harga. Namun secara } \\
\text { keseluruhan Kualitas } \\
\text { produk dan harga } \\
\text { berpengaruh secara }\end{array}$ \\
\hline
\end{tabular}




\begin{tabular}{|c|c|c|c|c|}
\hline & & $\begin{array}{l}\text { Sony Xperia } \\
\text { Z series di } \\
\text { counter } \\
\text { Insight Plaza } \\
\text { Marina } \\
\text { Surabaya }\end{array}$ & $\begin{array}{l}\text { Analisis linear } \\
\text { berganda dengan } \\
\text { bantuan SPSS }\end{array}$ & $\begin{array}{l}\text { signifikan yaitu secara } \\
\text { parsial maupun simultan } \\
\text { terhadap keputusan } \\
\text { pembelian smartphone } \\
\text { Sony Xperia Z series di } \\
\text { counter Insight Plaza } \\
\text { Marina Surabaya. }\end{array}$ \\
\hline 2. & $\begin{array}{l}\text { Ummu habibah \& } \\
\text { sumiati } \\
\text { (2016) }\end{array}$ & $\begin{array}{l}\text { Pengaruh } \\
\text { kualitas } \\
\text { produk dan } \\
\text { harga } \\
\text { terhadap } \\
\text { keputusan } \\
\text { pembelian } \\
\text { produk } \\
\text { kosmetik } \\
\text { wardah di } \\
\text { kota } \\
\text { Bangkalan } \\
\text { Madura }\end{array}$ & $\begin{array}{l}\text { Jenis penelitian: } \\
\text { Deskriptif } \\
\text { Variabel } \\
\text { 1.Kualitas } \\
\text { produk } \\
\text { 2.harga } \\
\text { 3.keputusan } \\
\text { pembelian } \\
\text { Analisis data: } \\
\text { Regresi linier } \\
\text { berganda }\end{array}$ & $\begin{array}{l}\text { Variabel independen } \\
\text { (kualitas produk dan } \\
\text { harga) yang memiliki } \\
\text { pengaruh paling dominan } \\
\text { terhadap variabel } \\
\text { dependen (keputusan } \\
\text { pembelian) adalah variabel } \\
\text { kualitas produk }\end{array}$ \\
\hline 3. & $\begin{array}{l}\text { Dedi Nurdiansyah } \\
\text { (2017) }\end{array}$ & $\begin{array}{l}\text { Pengaruh } \\
\text { kualitas } \\
\text { produk, harga } \\
\text { terhadap } \\
\text { keputusan } \\
\text { pembelian } \\
\text { produk sepatu } \\
\text { olahraga } \\
\text { merek Adidas } \\
\text { di Bandar } \\
\text { Lampung }\end{array}$ & $\begin{array}{l}\text { Jenis penelitian: } \\
\text { Deskriptif } \\
\text { verifikatif } \\
\text { Variabel: } \\
\text { 1.kualitas produk } \\
\text { 2.Harga } \\
\text { 3.keputusan } \\
\text { pembelian } \\
\text { Analisis data: } \\
\text { Analisis regresi } \\
\text { berganda }\end{array}$ & $\begin{array}{l}\text { Kualits produk dan harga } \\
\text { yaitu sama- } \\
\text { sama memiliki hasil yang } \\
\text { positif terhadap keputusan } \\
\text { pembelian, dengan } \\
\text { variabel yang paling } \\
\text { mendominasi adalah } \\
\text { kualitas produk sebagai } \\
\text { variabel yang } \\
\text { mempengaruhi keputusan } \\
\text { pembelian sepatu olahraga } \\
\text { merek Adidas di Bandar } \\
\text { Lampung }\end{array}$ \\
\hline 4. & $\begin{array}{l}\text { Rifqi sulthan } \\
\text { fahreezzy\& Arlin } \\
\text { ferlina } \\
\text { moch.trenggana } \\
\text { (2018) }\end{array}$ & $\begin{array}{l}\text { Kualitas } \\
\text { produk dan } \\
\text { harga } \\
\text { terhadap } \\
\text { keputusan } \\
\text { pembelian } \\
\text { konsumen } \\
\text { laptop Asus }\end{array}$ & $\begin{array}{l}\text { Jenis penelitian: } \\
\text { Kuantitatif } \\
\text { deskriptif } \\
\text { verifikatif } \\
\text { Alat analisis: } \\
\text { Analisis regresi } \\
\text { berganda }\end{array}$ & $\begin{array}{l}\text { Hasil perhitungan variabel } \\
\text { harga secara parsial } \\
\text { diketahui berpengaruh } \\
\text { secara signifikan terhadap } \\
\text { keputusan pembelian } \\
\text { konsumen laptop Asus. } \\
\text { Pengaruh variabel kualitas } \\
\text { produk dan harga secara } \\
\text { bersama-sama atau } \\
\text { simultan berpengaruh } \\
\text { positif terhadap keputusan } \\
\text { pembelian konsumen } \\
\text { laptop Asus. }\end{array}$ \\
\hline
\end{tabular}

Sumber : Eva Cahya, Harti (2015), Habibah\& Sumiati (2016), Nurdiansyah (2017),

Fahrezzy\&Trenggana (2018) 


\section{Pengertian Kualitas Produk}

Perusahaan untuk menjalankan suatu bisnisnya, produk ataupun jasa harus memiliki kualitas yng baik sesuai dengan harga yang mereka tawarkan supaya perusahaaan bisa bertahan dalam menghadapi persaingan,terutama persaingan dalam hal kualitas produk. Menurut (Kotler dan Keller 2012:49) mengemukakan bahwa kualitas adalah keseluruhan ciri serta sifat dari suatu produk atau pelayanan yang berpengaruh pada kemampuannya untuk memuaskan kebutuhan yang dinyatakan atau tersirat. Sedangkan menurut (Lupiyoadi dan Hamdani 2006:131) Konsumen akan menyukai produk yang menawarkan kualitas, kinerja, dan pelengkap inovatif yang terbaik.

Hal ini serupa dengan pendapat dari (Kotler \& Amstrong 2008:346) bahwa semakin baik kualitas produk yang dihasilkan maka akan memberikan kesempatan kepada konsumen untuk melakukan keputusan pembelian. (Kotler \& Amstrong 2008:347) menyatakan bahwa "kualitas produk adalah kemampuan suatu produk untuk melakukan fungsi-fungsinya yang meliputi daya tahan, keandalan, ketepatan, kemudahan, operasi dan perbaikan serta atribut lainnya”. Bila suatu produk berjalan sesuai dengan fungsinya maka dapat dikatakan sebagai produk yang berkualitas dengan baik. Perusahaan haruslah selalu meningkatkan kualitas produk atau jasanya yang dijual karana dengan kualitas produk yang baik maka konsumen akan puas dengan apa yang mereka beli dengan begitu akan mempengaruhi konsumen untuk melakukan pembelian ulang.

\section{Pengertian Harga}

Harga merupakan salah satu faktor penting dari sisi penyedia produk dan jasa untuk memenangkan persaingan dari para pesaing, untuk itu harga harus ditetapkan. Menurut (Tjiptono, 2008), harga merupakan suatu variabel penting dalam pemasaran, dimana harga dapat mempengaruhi konsumen dalanm mengambil keputusan untuk membeli suatu produk, karena berbagai alasan. Sedangkan Menurut (Kotler \& Amstrong 2009 : 73) harga adalah sejumlah uang yang ditukarkan untuk sebuah produk dan jasa.

Menurut Kotler \& Keller yang dialih bahasakan oleh (Bob Sabran 2009 : 67), harga adalah salah satu elemen bauran pemasaran yang menghasilkan pendapatan, elemen lain menghasilkan biaya. Dalam hal ini harga merupakan suatu cara bagi seorang penjual untuk membedakan penawarannya dari para pesaing. Sehingga penetapan harga dapat dipertimbangkan sebagai bagian dari fungsi diferensiasi barang dalam pemasaran. 
Dari definisi dari beberapa ahli tersebut, maka dapat disimpulkan bahwa harga adalah sejumlah nilai uang termasuk barang dan jasa yang ditawarkan untuk mengganti hak milik suatu barang dan jasa kepada pihak lain dan menjadi salah satu faktor penentu konsumen dalam menentukan keputusan pembelian terhadap produk dan jasa.

\section{Pengertian Keputusan Pembelian}

Suatu keputusan adalah suatu plihan yang dibuat untuk memilih suatu hal. Apabila tidak ada pilihan yang dibuat maka bisa dikatakan tidak dapat membuat keputusan. Menurut (Kotler, 2000:204) dalam (Ruhamak, 2016) tahap-tahap yang dilewati pembeli untuk mencapai keputusan membeli melewati lima tahap, yaitu: Pengenalan Masalah, pencarian Informasi, Evaluasi alternatif, Keputusan Membeli, tingkah laku pasca pembelian. Menurut (Assauri, 2010 : 139) keputusan pembelian merupakan suatu proses pengambilan keputusan akan pembelian yang mencakup penentuan apa yang akan dibeli atau tidak melakukan pembelian dan keputusan itu diperoleh dari kegiatan-kegiatan sebelumnya, sedangkan Menurut (Kotler dan Keller 2012:166)

Proses keputusan pembelian terdiri dari lima tahap yang dilakukan oleh seseorang konsumen sebelum sampai pada keputusan pembelian dan selanjutnya pasca pembelian. Keputusan pembelian ini dilakukan tidak terlepas dari kepuasan dan ketidak puasan pelanggan dalam pelayanan produk atau jasa, Untuk itu konsep keputusan pelanggan tidak lepas dari kepuasan pelanggan. Secara umun manusia akan selalu mempertimbangkan segala sesuatu sebelum mereka bertindak untuk mengurangi resiko yang nungkin muncul atas tindakan yang dilakukan.

\section{Kerangka Berpikir}

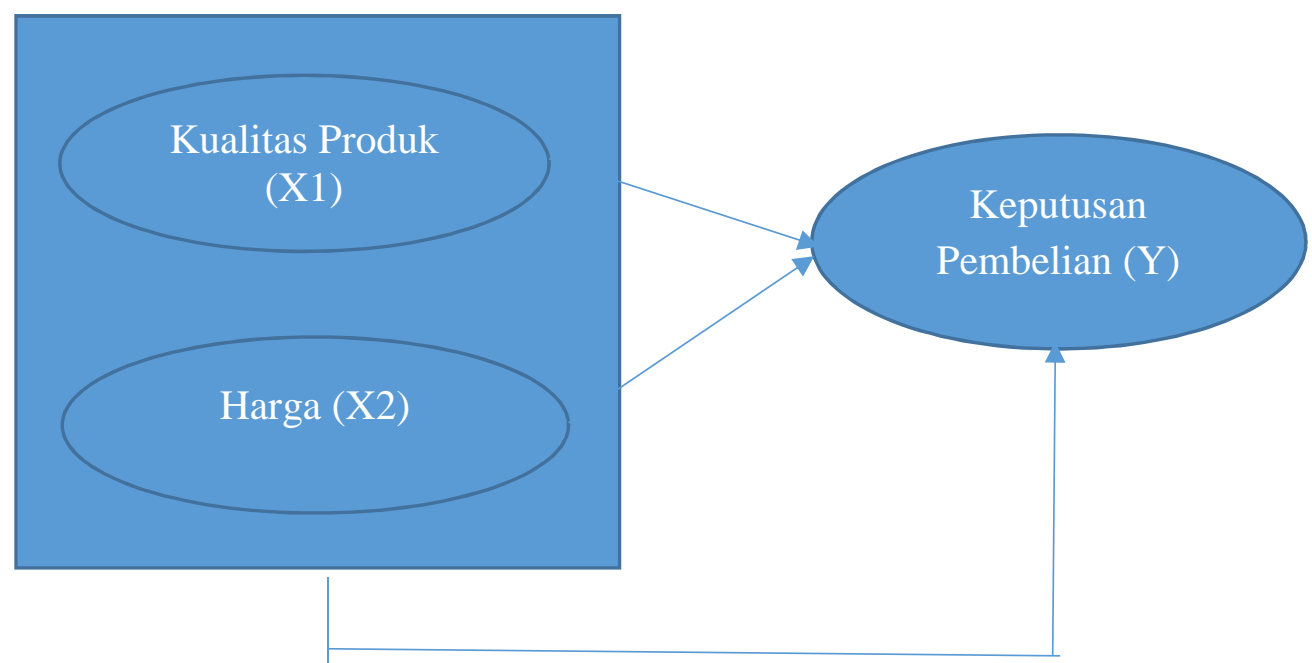




\section{Keterangan :}

$=\longrightarrow$ Berpengaruh secara parsial.

$=-\cdots \cdot \rightarrow$ Bepengaruh secara simultan.

\section{METODE PENELITIAN}

\section{Populasi Dan Sampel}

Populasi dalam penelitian ini adalah konsumen produk Wardah yang datang ke counter wardah di borobudur kediri. Dalam penelitian ini teknik pengambilan sampel yang digunakan adalah teknik purposive sampling, dimana sampel ini dipilih berdasarkan karakteristiknya. Dalam menentukan jumlah sampel peneliti menggunakan teori dari (Roscoe, 1975) yang dikutip (Uma ,Sekaran: 2006) memberikan acuan umum untuk menentukan ukuran sampel dalam penelitian multivariate (termasuk analisis regresi berganda), ukuran sampel sebaiknya10x lebih besar dari jumlah variabel dalam penelitian.

Dari hal itu maka jumlah sampel dalam penelitian ini dinyatakan sebanyak 30 responden

\section{Definisi Operasional}

Tabel 2. Indikator Definisi Operasional

\begin{tabular}{|c|c|c|c|}
\hline $\begin{array}{l}\text { VARIABEL } \\
\text { PENELITIAN }\end{array}$ & DEFINISI & INDIKATOR & $\begin{array}{c}\text { SKALA DAN } \\
\text { PENGUKURAN }\end{array}$ \\
\hline Kualitas produk (X1) & $\begin{array}{l}\text { Menurut (Kotler \& } \\
\text { Amstrong 2008:346) } \\
\text { Kualitas produk } \\
\text { adalah kemampuan } \\
\text { suatu produk untuk } \\
\text { melakukan fungsi- } \\
\text { fungsinya yang } \\
\text { meliputi daya tahan, } \\
\text { keandalan, ketepatan, } \\
\text { kemudahan, operasi } \\
\text { dan perbaikan serta } \\
\text { atribut lainya }\end{array}$ & $\begin{array}{l}\text { 1.Kinerja } \\
\text { (Perfomance) } \\
\text { 2. Keistimewaan } \\
\text { tambahan(Features) } \\
\text { 3. Keandalan } \\
\text { ( reliability) } \\
\text { 4. Kesesuaian dengan } \\
\text { Spesifikasi } \\
\text { (Comformance to } \\
\text { Spesification) } \\
\text { 5. Daya tahan } \\
\text { (Durability) } \\
\text { 6.Estetika(Asthethic) } \\
\text { 7. Dimensi } \\
\text { kemudahan perbaikan } \\
\text { (Serviceability) }\end{array}$ & Likert \\
\hline HARGA (X2) & $\begin{array}{l}\text { Menurut (Tjiptono, } \\
\text { 2008) Harga } \\
\text { merupakan suatu } \\
\text { variabel penting } \\
\text { dalam pemasaran, } \\
\text { dimana harga dapat } \\
\text { mempengaruhi }\end{array}$ & $\begin{array}{l}\text { 1.Jangkauan harga } \\
\text { dengan daya beli } \\
\text { konsumen } \\
\text { 2. Daya saing harga } \\
\text { dengan produk sejenis } \\
\text { 3. Kesesuaian harga } \\
\text { dengan kualitas }\end{array}$ & Likert \\
\hline
\end{tabular}




\begin{tabular}{|c|c|c|c|}
\hline & $\begin{array}{l}\text { konsumen dalam } \\
\text { mengambil keputusan } \\
\text { untuk membeli suatu } \\
\text { produk, karena } \\
\text { berbagai alasan. }\end{array}$ & & \\
\hline $\begin{array}{l}\text { Keputusan pembelian } \\
\text { (Y) }\end{array}$ & $\begin{array}{l}\text { Menurut (Assauri, } \\
2010: 139 \text { ) keputusan } \\
\text { pembelian merupakan } \\
\text { suatu proses } \\
\text { pengambilan } \\
\text { keputusan akan } \\
\text { pembelian yang } \\
\text { mencakup penentuan } \\
\text { apa yang akan dibeli } \\
\text { atau tidak melakukan } \\
\text { pembelian dan } \\
\text { keputusan itu } \\
\text { diperoleh dari } \\
\text { kegiatan-kegiatan } \\
\text { sebelumnya }\end{array}$ & $\begin{array}{l}\text { 1.Keputusan } \\
\text { pemilihan produk } \\
\text { 2. Keputusan } \\
\text { pemilihan merek } \\
\text { 3. Keputusan } \\
\text { pemilihan gerai } \\
\text { 4. Penentuan waktu } \\
\text { pembelian } \\
\text { 5. Jumlah pembelian } \\
\text { 6.Metode pembayaran }\end{array}$ & Likert \\
\hline
\end{tabular}

Jenis penelitian ini adalah penelitian asosiatif .

\section{HASIL PENELITIAN DAN PEMBAHASAN}

\section{Hasil Penelitian}

Untuk mempermudah mengidentifikasi responden dalam penelitian ini maka diperlukan gambaran mengenai karakteristik responden adapun karakteristiknya yaitu usia, pendidikan terakhir, pekerjaan. Untuk karakteristik berdasarkan usia menunjukan bahwa frekuensi responden berdasarkan usia telah diketahui bahwa mayoritas responden yang paling banyak adalah pada usia 22-27 (10 responden) telah melakukan pembelian produk kosmetik wardah.

Untuk frekuensi responden berdasarkan pekerjaan telah diketahui bahwa mayoritas responden yang paling banyak dalam hal pekerjaan adalah pegawai swasta yaitu sebesar 46,7\% (14 responden) yang telah melakukan pembelian kosmetik wardah di borobudur kediri. Frekuensi responden berdasarkan pendidikan telah diketahui bahwa mayoritas responden yang paling banyak dalam dalam pendidikan terakhir adalah SMA/sederajat yaitu sebesar $83.4 \%$ (25 responden) yang telah melakukan pembelian kosmetik wardah di borobudur kediri. 


\section{PEMBAHASAN}

\section{Uji Instrumen Penelitian}

\section{Uji Validitas}

Hasil validitas yang dilakukan dalam penelitian menunjukkan bahwa korelasi antara masing-masing indikator terhadap total skor dari setiap variabel menunjukkan hasil yang signifikan, dan menunjukkan bahwa $\mathrm{r}$ hitung $>\mathrm{r}$ tabel. Sehingga dapat disimpulkan bahwa semua item pertanyaan dinyatakan valid.

\section{Uji Reliabilitas}

Dari hasil uji reliabilitas yang telah dilakukann dapat disimpulkan bahwa semua item pernyataan adalah reliabel karena nilai Cronbach's Alpha untuk variabel tersebut lebih besar dari nilai pembanding 0,06. Sehingga untuk selanjutnya item-item pada masing-masing konsep variabel tersebut layak digunakan sebagai alat ukur.

\section{Analisis Deskriptif}

Dari tabel di atas dapat dilihat nilai rata-rata dari ketiga variabel sebagai berikut:

\section{Kualitas Produk (X1)}

Variabel Kualitas Produk dengan jumlah data N sebanyak 30 responden mempunyai nilai-rata 16,7000. Dimana angka ini menunjukkan bahwa responden menilai setuju terhadap pernyataan-pernyataan kualitas produk.

2. Harga (X2)

Variabel harga dengan jumlah data $\mathrm{N}$ sebanyak 30 responden mempunyai nilai rata-rata 16,9667 sehingga dengan begitu bisa disimpulkan bahwa responden cukup setuju dengan pernyataan-pernyataan harga

3. Keputusan Pembelian (Y)

Variabel keputusan pembelian dengan jumlah data $\mathrm{N}$ sebanyak 30 responden mempunyai nilai rata-rata sehingga dengan begitu bisa disimpulkan bahwa responden cukup setuju dengan pernyataan-pernyataan harga 16,8333 sehingga dengan begitu bisa disimpulkan bahwa responden menyetujui tentang pernyataan-pernyataan dari keputusan pembelian. Pada tabel di atas bisa dilihat nilai standard deviation untuk variabel Kualitas produk (X1), Harga (X2), dan Keputusan pembelian (Y), sehingga dapat diketahui bahwa jawaban responden cenderung menyetujui dari pernyataanpernyataan variabel kualitas produk(X1), Harga(X2), dan Keputusan pembelian (Y). 


\section{Uji Analisis Regresi Linier Berganda}

Hasil perhitungan yang menggunakan program SPSS 22 dalam tabel 1.2 berikut ini:

\section{Coefficients $^{\mathrm{a}}$}

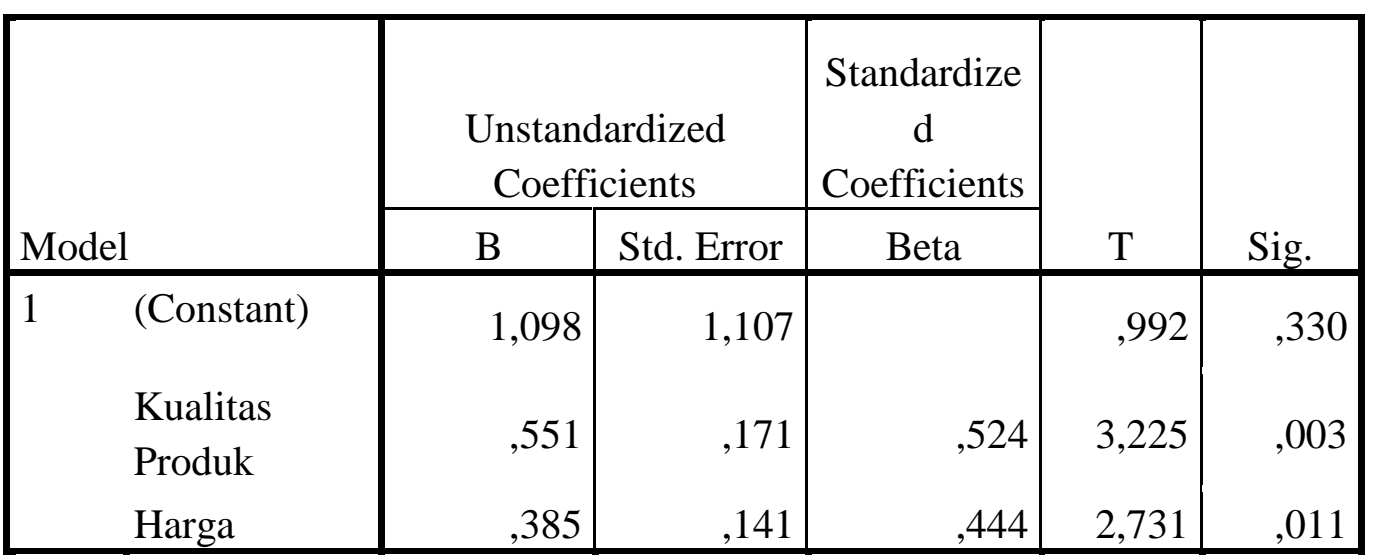

a. Dependent Variable: Keputusan Pembelian

Sehingga dengan begitu kita bisa memasukan nilai dari tabel hasil analisis regresi berganda yaitu

$$
Y=1,098+0,551 X 1+0,385 X 2
$$

\section{Uji Hipotesis}

Dengan melihat data pada tabel 4.10 maka dapat diketahui bahwa:

H1: Nilai regresi dari variabel kualitas produk (X1) adalah sebesar 3,225 dengan nilai positif sehingga bisa diartikan bahwa kualitas produk berpengaruh positif terhadap keputusan pembelian. Berpengaruh positif dapat diartikan jika kualitas produk semakin baik akan mempengaruhi keputusan pembelian.

H2: Nilai regresi dari variabel harga (X2) adalah sebesar 2,731 dengan nilai positif sehingga bisa diartikan bahwa harga mempengaruhi keputusan pembelian. Berpengaruh positif ini dapat diartikan bahwa harga mempengaruhi keputusan pembelian jika harga yang ditawarkan cukup terjangkau maka akan mempengaruhi keputusan pembelian.

Pengambilan keputusan berdasarkan nilai signifikansi adalah sebagai berikut:

Hipotesis:

Ho: Variabel kualitas produk (X1) dan harga (X2) tidak berpengaruh signifikan terhadap keputusan pembelian ( Y)

Ha: Terdapat pengaruh signifikan antara variabel-variabel independent (kualitas produk, harga) terhadap variabel dependent (keputusan pembelian)

Pengambilan keputusan : 
Jika probabilitas $>0.5$ maka Ho dierima, dan Ha ditolak.

Jika probabilitas $<0.5$ maka Ho ditolak, dan Ha diterima..

Hasil:

H1: Diketahui nilai $\mathrm{T}$ hitung sebesar 3,225 > nilai dari $\mathrm{T}$ tabel sebesar 2,052 dan nilai signifikansi sebesar $0,003<0,5$ maka Ho ditolak dan Ha diterima yang artinya kualitas produk berpengaruh terhadap keputusan pembelian.

H2 : diketahui nilai $\mathrm{T}$ hitung sebesar 2,731 > T tabel sebesar 2,052 dan nilai signifikansi sebesar 0,011 < 0,5. Maka Ho ditolak dan Ha diterima yang artinya variabel harga berpengaruh signifikan terhadap keputusan pembelian

\section{Hasil Uji F (Uji Simultan)}

Dari uji f yang telah dilakukan dapat disimpulkan bahwa nilai signifikansi sebesar $0,000<0,05$ dan $\mathrm{F}$ hitung sebesar 125,475 > F tabel 3,34. Maka H3 diterima yang berarti ada pengaruh signifikan secara simultan antara variabel kualitas produk dan harga berpengaruh secara bersama-sama terhadap keputusan pembelian.

\section{Koefisien Determinasi $\left(\mathbf{R}^{2}\right)$}

Berdasarkan output diatas diketahui nilai R Square 0,903, hal ini mengandung arti bahwa pengaruh variabel kualitas produk (X1) dan dan harga (X2) secara simultan terhadap variabel keputusan pembelian (Y) adalah sebesar 90,3\% dan sisanya sebesar 9,7\% dipengaruhi oleh faktor lain diluar kualitas produk dan harga.

\section{PEMBAHASAN}

Berdasarkan hasil pengujian secara statistik dapat terlihat dengan jelas bahwa secara parsial semua variabel bebas berpengaruh terhadap variabel terikat. Pengaruh yang diberikan kedua variabel bebas tersebut bersifat positif dan signifikan artinya semakin baik kualitas produk serta semakin terjangkaunya harga yang ditawarkan maka akan semakin tinggi keputusan pembelian yang dilakukan oleh para konsumen. Hasil penelitian ini sesuai dengan hipotesis yang diajukan. Penjelasan dari masing-masing pengaruh variabel sebagai berikut: 


\section{Pengaruh Kualitas Produk Terhadap Keputusan Pembelian}

Hasil pengujian hipotesis (H1) telah membuktikan bahwa terdapat pengaruh antara harga terhadap keputusan pembelian diketahui nilai $\mathrm{T}$ hitung sebesar 3,225> nilai dari $\mathrm{T}$ tabel sebesar 2,052 dan nilai signifikansi sebesar 0,003<0,5 maka Ho ditolak dan Ha diterima yanga artinya kualitas produk berpengaruh terhadap keputusan pembelian. Kualitas produk berpengaruh terhadap keputusan pembelian konsumen pada kosmetik Wardah di counter wardah di borobudur kediri. Sebab produk yang berkualitas akan mempengaruhi konsumen yang berdampak pada keputusan pembelian melalui desain dan variasi dan lain-lain. Melalui kualitas produk yang baik konsumen akan merasa aman saat membeli produk yang nantinya memicu terjadinya keputusan pembelian oleh konsumen tersebut.

Memiliki kualitas produk yang baik membuat kosmetik mendapat keuntungan dalam bentuk pembelian ulang yang dilakukan oleh konsumen. Konsumen yang melakukan pembelian ulang tentunya akan memiliki presepsi bahwa kosmetik tersebut memiliki kualitas dan keamanan yang baik.

\section{Pengaruh Harga Terhadap Keputusan Pembelian}

Hasil pengujian hipotesis (H2) telah membuktikan bahwa terdapat pengaruh antara harga terhadap keputusan pembelian diketahui $\mathrm{T}$ hitung sebesar 2,731 > T tabel sebesar 2,052 dan nilai signifikansi sebesar 0,011<0,5.

Maka Ho ditolak dan Ha diterima yang artinya variabel harga berpengaruh signifikan terhadap keputusan pembelian.

Harga menentukan keputusan pembelian konsumen, harga memiliki arti penting , karena harga merupakan salah satu atribut yang paling penting yang menjadi pertimbangan dalam pengambilan keputusan, pengambilan keputusan pembelian dilihat dari sudut pandang harga ini digunakan konsumen untuk memutuskan cara mendapatkan manfaat dan nilai daya belinya. Harga yang ditawarkan harus terjangkau dan sesuai dengan pendapatan konsumen. 


\section{KESIMPULAN}

Berdasarkan hasil penelitian yang telah dilakukan, maka dapat diambil kesimpulan sebagai berikut:

1. Ada pengaruh yang signifikan antara kualitas produk terhadap keputusan pembelian produk kosmetik wardah (studi kasus counter wardah di Borobudur Kediri dengan memperoleh nilai $\mathrm{T}$ hitung lebih besar dari $\mathrm{T}$ tabel

2. Ada pengaruh yang signifikan antara harga terhadap keputusan pembelian produk kosmetik wardah (studi kasus counter wardah di Borobudur Kediri dengan memperoleh nilai $\mathrm{T}$ hitung lebih besar dari $\mathrm{T}$ tabel

3. Ada pengaruh yang signifikan secara bersama-sama antara kualitas produk dan harga terhadap keputusan pembelian produk kosmetik wardah (studi kasus counter wardah di Borobudur Kediri dengan memperoleh nilai signifikansi sebesar 0,000 < 0,05 dan F hitung sebesar 125,475 > F tabel 3,34.

4. Hasil analisis regresi linear berganda Koefisien regresi dari semua variabel bebas menunjukkan angka positif. Hal ini berarti semua variabel bebas mempunyai hubungan yang positif terhadap variabel terikatnya.

Dari kedua variabel bebas yang paling dominan berpengaruh adalah Kualitas produk (X1) dengan koefisien regresi sebesar 0,551sedangkan untuk variabel harga(X2) sebesar 0,385 .

\section{DAFTAR PUSTAKA}

Akbar, Adam. 2012. Analisis Pengaruh Citra Merek, Harga, dan Kualitas Produk terhadap Keputusan Pembelian: Hal 1-21

Arlin Ferlina Moch. Trenggana dan Rifqi Sulthan Fahrezzy. 2018. Pengaruh Kualitas produk dan Harga terhadap Keputusan Pembelian Konsumen Laptop ASUS. Vol. 17, No. 2, Mei-Agustus 2018: Hal 174-183

Arriapple.blogspot.com/2016/04/Pengertian-dan-fungsi-skala-pengukuran.html?m=1

Assauri, Sofjan. 2010. Manajemen Pemasaran. Jakarta : Raja Grafindo Persada

Buchari, Alma. 2005. Manajemen Pemasaran dan Pemasaran Jasa. Bandung: Alfabeta. Buchari, Alma. 2011. Manajemen Pemasaran dan Pemasaran Jasa. Bndung: Alfabeta.

Eva Cahya, Harti. 2015. Pengaruh Kualitas Produk dan Harga Terhadap Keputusan Pembelian Smartphone Sony Xperia Z Series di Counter Insight Plaza Marina Surabaya: Hal 1-15

Ghozali, Imam. 2011. Aplikasi Analisis Multivariate dengan Program IBM SPSS19. Semarang: Badan Penerbit Universitas Diponegoro

Harini, 2008. Makroekonomi Pengantar. Jakarta: PT. Gramedia Pustaka Utama http://asihrahmawati1025.bogspot.com/2013/02/pt-paragon-technologi-andinnovation_2575.html?m=1 
Husein, Umar. 2002. Metode Riset Bisnis. Jakarta: PT Gramedia

Kotler, Philip \& Kevin Lane Keller. 2008. Manajemen Pemasaran. Edisi 13. Jilid 1.Jakarta

Kotler, Philip and Amstrong, Garry, 2008. Prinsip-Prinsip Pemasaran. Jilid satu. Jakarta: Erlangga

Kotler, Philip and Amstrong, Garry, 2009. Prinsip-Prinsip Pemasaran. Jilid dua. Jakarta: Erlangga

Kotler, Philip and Amstrong, Garry. 2006. Dasar-dasar Pemasaran. Edisi kesembilan jilid satu. Jakarta: Penerbit indeks

Kotler, Philip and Amstrong, Gary. 2012. Priciples of Marketing Global 14the edition. New Jersey: Prentice.

Kotler, Philip and Keller, Kevin Lane. 2012. Marketing Management. 14th edition. New Jersey: Prentice.

Kotler, Philip. 2009. Manajemen Pemasaran. Jakarta: Erlangga

Lupiyoadi, Rambat dan A. Hamdani. 2006. Manajemen Pemasaran Jasa. Jakarta: Salemba Empat

Malhotra, Naresh K. 2009. Riset Pemasaran Pendekatan Terapan Jilid 1. Jakarta: PT Index.

Ruhamak, M. D. (2016). Analisis faktor yang mempengaruhi konsumen dalam pengambilan keputusan pembelian produk air minum merk aqua. Jurnal EkoNika, 1(1), 38-49. Retrieved from http://ojs.unik kediri.ac.id/ index.php/e konika/article/view/4/12

Nurdiansyah, Dedi. 2017. Pengaruh Kualitas Produk dan Harga terhadap Keputusan Pembelian Produk Sepatu Olahraga Merek ADIDAS di Bandar Lampung, SKRIPSI. Universitas Lampung, Fakultas Ekonomi dan Bisnis: Hal 1-68

Lestari, R. (2016). Analisis Efek Promosi dan Discount Terhadap Impulse Buying (Studi Kasus Konsumen Mall Kediri Town Square). Jurnal Nusamba, 1(2), 27-37. https://doi.org/https://doi.org/10.29407/nusamba.v1i2.460

Sanusi, Anwar. 2011. Metedologi Penelitian Bisnis. Jakarta Selatan: Salemba Empat

Siregar, Charles. JP., 2004. Farmasi Rumah Sakit Teori dan Penerapan. Cetakan 1, Penerbit EGC, Jakarta

Sugiyono. 2011. Metode penelitian Kuantitatif, kualitatif dan $R \& B$. Bandung: Alfabeta Suliyanto. 2006. Metode Riset Bisnis. Yogyakarta: Penerbit Andi

Sumiati dan Habibah, Ummu. 2016. Pengaruh Kualitas Produk dan Harga terhadap Keputusan Pembelian Produk Kosmetik Wardah di Kota Bangkalan Madura. Vol. 1, No. 1, Maret 2016 : Hal 31-48.

Tjiptono, Fandy. 2008. Strategi Pemasaran. Edisi ketiga. Yogyakarta: Andi offset Weenas, Jakson R.S. 2013. Kualitas Produk, Harga, Promosi, dan Kualitas Pelayanan Pengaruhnya terhadap Keputusan Pembelian Spring Bed Comforta. Vol. 1, No. 4, Desember 2013 : Hal 607-618

www.topbrand-award.com 